In this issue:

Organizations Endorsing the Joint Statement on Faculty Status

UCSC Library Starts Move into New Addition

News from the Field

Publications

People

Classified Advertising

\title{
Organizations Endorsing the Joint Statement on Faculty Status
}

The following organizations have endorsed the "Joint Statement on Faculty Status of College and University Librarians," which was published in the February 1974 issue of College \& Research Libraries News.

Association of College and

Research Libraries

June 1972

Colorado Library Association December 1972

American Association of

University Professors

Wisconsin Association of

Academic Librarians

Maryland Library Association

Washington Library Association,

Association of Academic and

Research Librarians

Southeastern Library Association

New Mexico Library Association

District of Columbia Library

Association

Mississippi Library Association

Illinois Library Association

West Virginia Library Association

Tennessee Library Association

Virginia Library Association

Oregon Library Association

Southwestern Library Association

Ohio Library Association

Florida Library Association

Missouri Library Association

California Library

Association

Special Libraries Association
April 1973

April 1973

April 1973

May 1973

July 1973

July 1973

July 1973

July 1973

July 1973

July 1973

July 1973

August 1973

September 1973

September 1973

September 1973

September 1973

September 1973

September 1973

October 1973
North Dakota Library

Association

Association of Research Libraries*

South Carolina Library Association

Kentucky Library Association,

College and Research

Section

Wisconsin Library Association

New Jersey Library

Association

October 1973

October 1973

October 1973

October 1973

October 1973

October 1973

Georgia Library Association,

College and University

Section

Georgia Library Association

Minnesota Library Association, Academic Division

Theatre Library Association

Rhode Island Library

Association

North Carolina Library

Association, College and

University Section

Kentucky Library

Association

Association of American

Library Schools

October 1973

October 1973

October 1973

October 1973

November 1973

November 1973

December 1973

January 1974

"VOTED "that the Board endorse in principle faculty status for professional librarians, and commend to the attention of all college and university administrations the "Joint Statement on Faculty Status of College and University Librarians." 
Music Library Association

Mountain Plains Library Association

January 1974

Pennsylvania Library Association,

College and Research

Library Division

Oklahoma Library Association

Wyoming Library Association, Academic and Special

Libraries Section

Wyoming Library Association

Montana Library Association,

Academic and Special

Libraries Division

Medical Library Association

\section{March 1974}

March 1974

April 1974

April 1974

April 1974

May 1974

June 1974
New York Library Association, College and University

Libraries Section

September 1974

St. Croix Library

Association

September 1974

Library Association of the City

University of New York

May 1975

Academic Library Association of Ohio

July 1975

Louisiana Library Association, Academic Section

April 1976

American Historical Association

October 1976

\section{UCSC Library Starts Move into New Addition}

The "big move" is on.

Two years ago-in November of 1974ground was broken for a five-story, 43,000square-foot addition to the Dean E. McHenry Library at University of California, Santa Cruz.

In November, with completion of the new $\$ 2.8$ million extension, staff began the job of

\section{Recruitment Open for Editor of ACRL Publications in Librarianship}

ACRL's highly esteemed monographic series, ACRL Publications in Librarianship, will require a new editor in June, when current editor Kenneth G. Peterson will complete a five-year nonrenewable term. A subcommittee of the ACRL Publications Committee is now accepting applications for this volunteer professional post and will make a recommendation to the ACRL president before the Annual Conference.

Besides ACRL membership, persons seeking the appointment should offer a background of service in academic or research librarianship, experience in research, editing, and bibliographical activities, the ability to analyze manuscripts for content, research methods, form, structure, and style, and a concern with publication as a means of professional communication.

Inquiries and expressions of interest, accompanied by a statement of qualifications, should be sent to Nina Cohen, Chairperson, Search Subcommittee for ACRL Publications in Librarianship Editor, Wesleyan University Library, Middletown, CT 06457 by April 1 . rearranging some 350,000 books within the expanded building and shelving another 50,000 books which, until now, had been held in storage.

The major part of the project-erecting several hundred shelving units, putting them in place, and filling them with books-is expected to take "about two months," according to Associate University Librarian Wendell Simons, who is in charge of the move.

"It's good to have some elbow room," says University Librarian David Heron, noting that the library's core collection of 80,000 books has increased to 515,000 volumes in the 11 years since the campus accepted its first students. "With this new addition," he adds, "we now

News items for inclusion in C\&RL News should be sent to John $V$. Crowley. Assistant Director of Libraries, Milne Library, State University College. Oneonta, NY 13820. Advertising (including classilied ads) should be sent to Leona Swiech, Advertising Olfice, American Library Association, 50 E. Huron St., Chicago, IL 606II. Production and circulation matters are handled by ALA Central Production Unit, at the above address.

News edifor: John V. Crowley, Assistant Director of Libraries, Milne Library, State University College, Oneonta NY 13820. Editor: Richard D. Johnson, Milne Library, State University College, Oneonta, New York I3820. President, ACRL: Connie R. Dunlap. Executive Secretary, ACRL: to be announced.

College 2 Research Libraries is published by the Association of College and Research Libraries, a division of the American Library Association, 17 times yearly-6 bimonthly journal issues and II monthly (combining July-August) News issues-at |201-05 Bluff St. Fulton. MO 6525|. Subscription, $\$ 15.00$ a year or to mambers of the division, $\$ 7.50$, included in dues. Second-class postage paid at Fulton, Missouri 65251.

(C) American Library Association 1977. All material in this journal subject to copyright by the American Library Association may be photocopied for the noncommercial purpose of scientific or educational advancement. 